\title{
Metafrontier Analysis of Access to Credit and Technical Efficiency among Smallholder Cocoa Farmers in Southwest Nigeria
}

\author{
Awotide D. O. ${ }^{1}$, Kehinde, A. L. ${ }^{2} \&$ Akorede, T. O. ${ }^{1}$ \\ ${ }^{1}$ Department of Agricultural Economics and Farm Management, Olabisi Onabanjo University, Yewa Campus, \\ Ayetoro, Ogun State, Nigeria \\ ${ }^{2}$ Department of Agricultural Economics and Extension, Osun State University, Ejigbo Campus, Ejigbo, Osun \\ State, Nigeria \\ Correspondence: Awotide D. O., Department of Agricultural Economics and Farm Management, Olabisi \\ Onabanjo University, Yewa Campus, Ayetoro, Ogun State, Nigeria. Tel: 234-803-345-3423. E-mail: \\ w_awotide@yahoo.com
}

Received: October 10, 2014

Accepted: November 19, 2014

Online Published: December 25, 2014

doi:10.5539/ibr.v8n1p

URL: http://dx.doi.org/10.5539/ibr.v8n1p132

\begin{abstract}
It has been identified that limited access to timely credit has been a major constraint militating against increased agricultural productivity by farmers. Studies have shown that a large percentage of farmers faced with credit constraints have low production efficiencies. This study empirically investigated access to credit and technical efficiency (TE) of cocoa farmers in southwest Nigeria. The Study was conducted in Ogun State, southwest Nigeria. Primary data used for the study were collected in 2012 through a multi-stage sampling technique to select 240 cocoa farmers in the four (4) divisions of Ogun State. Data collected were analyzed using descriptive statistics, and Stochastic Metaproduction Frontier analyses. Tobit Regression Model was used to analyze the relationship between access to credit and technical efficiency among cocoa farmers in the study area. The study revealed that majority of the cocoa farmers did not have access to credit from formal institution implying negative consequences for agricultural productivity and household income generation. Most of the farmers borrowed relatively small size of loans for short duration. Estimates of the stochastic frontier models showed that cocoa farms in Ogun State had mean technical efficiency scores of 0.41, 0.94, 0.32 and 0.71 for farms in Yewa, Ijebu, Remo and Egba respectively. The results for the inefficiency model showed that age, education, experience, membership association, marital status, occupation, livelihood income, household size, and labour cost had significant effect on cocoa farmers in at least one division. The values of the Technology Gap Ration (TGR), together with the technical efficiencies obtained from the divisional stochastic frontiers (TE) and the metafrontier ( $\left.\mathrm{TE}^{*}\right)$ were computed for all farmers in Ogun State. These results implied that the mean producer in Ijebu and Egba, if he or she were technically efficient, could still increase output by $6 \%$ and $29 \%$, if he or she were to adopt the most efficient meta-technology for the division. Finally, there was a significant relationship between access to credit and technical efficiency of cocoa farmers. Evidence from the study revealed that majority of the poor cocoa farmers do not have access to credit from formal institution. Evidence from the metaproduction frontier showed that the mean productivity potential and technical efficiency ratios give additional explanation compared to the analysis based only on individual stochastic production frontiers. The productivity potential ratio plays an important part in explaining the ability of cocoa farmers in one division to compete with other farmers from different division at the state level. Based on the results, policy environment whereby individual cocoa farmers may have access to formal credit from banks and other agency, by forming groups, by means of using land use right certificates and also guarantor as a collateral would be a right direction in boosting cocoa production in the sub-region.
\end{abstract}

Keywords: access to credit, technical efficiency, cocoa farmers, metafrontier, Nigeria

\section{Introduction}

Agriculture still remains the mainstay of the economy of most African states, yet a current estimate indicates that some 200 million people or $28 \%$ of African's population are chronically hungry and the agricultural sector remains the engine room for sustainable growth of the Nigerian economy. Nigerian agriculture is characterized by considerable regional and crop diversity. In the 1960s, the agricultural sector was the most important in terms 
of contributions to domestic production, employment and foreign exchange earnings. Despite Nigeria's rich agricultural resource endowment, the agricultural sector has been growing at a very low rate. Less than $50 \%$ of the country's cultivable agricultural land is under cultivation. Even then, smallholder and traditional farmers who use rudimentary production techniques with resultant low yields, cultivate most of this land. The smallholder farmers are constrained by many problems including those of poor access to modern inputs and credit, poor infrastructure, inadequate access to markets, land and environmental degradation and inadequate research and extension services.

The Nigerian cocoa economy has a rich history which is well documented in literature. The contributions of cocoa to the nation's economic development are vast and have been reported by many authors (Olayide, 1969; Olayemi, 1973; Abang, 1984; and Folayan et al., 2006). In terms of foreign exchange earnings, no single agricultural export commodity has earned more than cocoa. With respect to employment, the cocoa sub-sector has not provided sizeable number of people with employment opportunities, both directly and indirectly. In addition, it is an important source of raw materials, as well as source of revenue to governments of cocoa producing states. Cocoa is one of the most widely produced agricultural cash crops in the West African countries. It is a vital source of foreign exchange, investment, and economic growth. Cocoa production raises over \$2 billion in foreign exchange for the sub region while taxation of the sector generates significant government revenues. The average country cocoa yield is between 300 and 400kg per hectare while approximately 7 million ha of land is currently in cocoa production in these countries involving approximately 2 millions households (Vos et al., 2002).

\section{Access to Credit and Agricultural Productivity in Nigeria}

The agricultural sector in Nigeria is predominantly dominated by peasant farmers, characterized by low level of income and saving capacity. It has been identified that limited access to timely credit has been a major constraint militating against robust investments and increased agricultural productivity by farmers (Ajakaiye, 1991; Ogunma, 1998; Manyong et al., 2004). One way to improve farmers' capital investment is by providing them with timely and targeted accessible credit to boost production and income because of the clear knowledge of the time specific nature of some farm operations. Credit is one of the components of financial services considered fundamental in all production units (Dicken, 2007). There have been a general awareness of the significance of credit as a tool for agricultural development (Omonona et al., 2008). Likewise there is a growing interest recently, in understanding the impact of financial structure on production as well as on the efficiency of production (Barry \& Robinson, 2001). Credit for rural smallholders especially in agriculture is assuming increasing importance in many parts of the world in response to the needs of less privilege entrepreneurs with limited capital base.

However, that lack of access to credit by poor rural households had been the bane of agricultural productivity, income generation and household welfare. With poor access to credit, it will be impossible to purchase inputs needed for production let alone maximizing output from given resources or minimizing the resources required for producing a given level of output. Growing empirical literature suggests that in rural areas of developing countries, credit constraints have significant adverse effects on farm output (Feder et al., 1990; Sial \& Carter, 1996; Petrick, 2004) and farm profit (Carter, 1989; Awotide et al., 2009). In Nigeria, the prevalence of credit constraints and their impact on production efficiency as led to low productions on the farms.

Economic theory indicates that the major goal of agricultural production at the micro-level has the objective of profit maximization through efficient farm allocation of resources over a period of time or by either maximizing output from given resources or minimizing the resources required for producing a given level of output. Therefore, good access to credit can therefore significantly increase the ability of cocoa farmers with little or no savings to acquire agricultural inputs. Furthermore, easing potential capital constraints through the credit reduces the opportunity costs of capital-intensive assets relative to family labour, thus encouraging the adoption of high yielding technologies such as Integrated Crop and Pest Management (ICPM) and therefore increasing land and labour productivity, a crucial factor in encouraging development, particularly in many West African cocoa countries.

Also, lack of adequate access to credit is in turn believed to have significant negative consequences on various aggregate and household level-incomes, including technology adoption, agricultural productivity, and the overall household welfare. Credit constraints have both direct and indirect effects on farm production. Directly, it affects the purchasing power of cocoa farmers to procure farm implement, and make farm related investments which they can fall back on to help them overcome credit constraints difficulty. Indirectly, it affects the risk behaviour of cocoa farmers (Eswaran \& Kotwal, 1990; and Guirkinger \& Boucher, 2005). Furthermore, a credit 
constrained farmer will likely invest in less risky and less productive technologies rather than in the more risky and but productive ones. This risk behavior has negative effects on technical efficiency of the farmers in that it limits the effort of the farmer in attaining maximum possible output hence, efficiency is compromised.

Studies have shown that a large percentage of farmers faced with credit constraints have low production efficiencies (Hussien \& Olhmer, 2008; Coelli, 1995; Bravo \& Pinheiro, 1997, and Awotide et al., 2009). The inability of most peasant farmers to have access to adequate capital has heightened the problem of low efficiency in production. Thus, it becomes imperative to study access to credit by the cocoa farmers. This study empirically investigates access to credit and technical efficiency of cocoa farmers in Yewa Division of Ogun State with a view to provide some informed basis for more investments in the sub-sector. This will help to improve access to credit and consequently efficiency in the production of cocoa. This also has implications for coca incomes for producers and exporters.

\section{The Metafrontier Approach}

\subsection{Stochastic Frontier Metaproduction Approach}

Further developments of the stochastic frontier model led to the stochastic frontier metaproduction model. Hayami (1969) and Hayami and Ruttan (1970) introduced the concept of metaproduction function for the assessment of efficiency. They defined the metaproduction function as "the envelope of commonly conceived neoclassical production functions". Thus, it is a common underlying production function that is used to represent the input-output relationship of a given industry (Lau \& Yotopoulos 1989). The metaproduction function concept is based on the hypothesis that all producers in different groups have potential access to the same technology. However, each producer may choose to operate on a different part of it depending on circumstances such as the natural endowments, relative prices of inputs, and the economic environment (Lau \& Yotopoulos, 1989). Recent extensions and modification of the stochastic frontier metaproduction function approach is found in Battese and Rao (2001), as discussed below.

Battese and Rao (2001), showed how technical efficiency scores for firms across regions can be estimated using a stochastic frontier metaproduction function model, and used a decomposition result to present an analysis of regional productivity potential and efficiency levels. If stochastic frontier models are defined for different regions within an industry, and for the jth region, there exist sample data on firms that produce one output from the various inputs. The stochastic frontier model for this region is specified as:

$$
Y_{i j}=f\left(x_{i j}, \beta_{j}\right) e^{V_{i j}-U_{i j}}, i=1,2, \ldots, N_{j}
$$

It is assumed that the $V_{i j} \mathrm{~s}$ are identically and independently distributed as $N\left(0, \sigma_{v}{ }^{2}\right)$ - random variables, independent of the $\mathrm{U}_{\mathrm{ij}} \mathrm{s}$, which are defined by the truncation (at zero) of the $N\left(0, \sigma_{v}{ }^{2}\right)$-distributions. Omitting the subscript $\mathrm{j}$ to simplify the model for the $j$ th group gives

$$
Y_{i}=f\left(x_{i}, \beta\right) e^{V_{i}-U_{i}} \equiv e^{x_{i} \beta+V_{i}-U_{i}}
$$

The stochastic frontier metaproduction function model for all firms in all regions of the industry is defined as

$$
Y_{i}=f\left(x_{i}, \beta^{*}\right) e^{V_{i}^{*}-U_{i}^{*}} \equiv e^{x_{i} \beta^{*}+V_{i}^{*}-U_{i}^{*}}, i=1,2, \ldots, N
$$

where ${ }^{N=\sum_{j=1}^{R} N_{j}}$ is the total number of sample firms in all (R) regions.

The maximum-likelihood estimates of the parameters of the above stochastic frontier metaproduction function do not necessarily result in the estimated function being an envelope of the individual regional production functions. This is because if the assumptions for the regional frontiers are satisfied, those associated with the stochastic frontier metaproduction function may not be satisfied. However, Battese and Rao (2001) discussed that it is possible to constraint the estimation of the metaproduction function (equation 3) such that it is an envelope of observations for efficient firms in all regions. Battese and Rao (2001) showed that the model for the $j$ th group and the stochastic frontier metaproduction function yields the following identity relationship:

$$
1=\frac{e^{x i \beta}}{e^{x i \beta}} \cdot \frac{e^{v t}}{e^{v t}} \cdot \frac{e^{-u t}}{e^{-u t}} .
$$

Where the three ratios on the right-hand side of the above equation are called productivity potential ratio (PPR), 
the random error ratio (RER) and the technical efficiency ratio (TER), respectively

$$
P P R_{i} \equiv \frac{e^{x i \beta}}{e^{x i \beta \cdot}} \equiv e^{-x i(\beta \cdot-\beta)}, R E R_{i} \equiv \frac{e^{v t}}{e^{v t}} \equiv e^{v i-v t}, \text { and } T E R_{i} \equiv \frac{e^{-u t}}{e^{-u t}} \equiv \frac{T E}{T E *}
$$

Battese and Rao (2001) defined the productivity potential ratio as the potential productivity increases for the given region, according to currently available technology for firms in a given region relative to the technology available in the whole industry. The technical efficiency of firm $i$, relative to its regional frontier, TE $\equiv e^{-u t}$, is estimated by $T E \equiv E\left(e^{-u t} / E i \equiv V_{i}-U_{i}\right)$, and the technical efficiency of firm i, relative to the metaproduction frontier is estimated as

\subsection{Stochastic Metafrontier Approach}

$$
T E \equiv E\left(e^{-u t} / E i \equiv V_{i}^{*}-U_{i}^{*}\right) . E_{i}^{*} \equiv E i-x i\left(\beta^{*}-\beta\right)
$$

The stochastic metafrontier model is an extension of the metaproduction function model. The technique proposed by Battese and Rao (2002) is used to measure of technical efficiency ratios as well as technology gap ratios for firms in a group relative to the best practice in the industry. Similar to the stochastic frontier metaproduction function, the stochastic metafrontier function is expressed as in equation (3). However, Battese and Rao (2002) explained that the metafrontier function is an envelope of the stochastic frontiers of the different groups such that it is defined by all observations in the different groups in a way that is consistent with the specifications of a stochastic frontier model. Observations on individual firms in the different groups may be greater than the deterministic component of the stochastic frontier model, but deviations from the stochastic frontier outputs are due to inefficiency of the firms in the different groups. The stochastic frontiers for the different groups and that of the metafrontier would generally be assumed to be of the same functional form (for example Cobb-Douglas or translog), but there are no problems of aggregation as with the relationship between firm and industry functions.

It is easily identified that the identity relationship in equation (4) of the stochastic frontier metaproduction function also holds for the stochastic metafrontier function. However, for the stochastic metafrontier function, the three ratios on the right-hand side of equation (4) are called the technology gap ratio (TGR), the random error ratio (RER) and the technical efficiency ratio (TER). Thus

$$
T G R_{i} \equiv \frac{e^{x i \beta}}{e^{x i \beta} .} \equiv e^{-x i(\beta \cdot-\beta)}, R E R_{i} \equiv \frac{e^{v t}}{e^{v t}} \equiv e^{v i-v t}, \text { and } T E R_{i} \equiv \frac{e^{-u t}}{e^{-u t}} \equiv \frac{T E i}{T E i}
$$

According to Battese and Rao (2002), the technology gap ratio indicates the technology gap for the given group according to currently available technology for firms in that group, relative to the technology available in the whole industry. The technical efficiency of firm i, relative to its regional frontier, TE $\equiv e^{-u t}$, is estimated by $T E \equiv E\left(e^{-u t} / E i \equiv V_{i}-U_{i}\right)$, and the technical efficiency of firm i, relative to the metaproduction frontier is estimated as $T E \equiv E\left(e^{-u t} / E i \equiv V_{i}^{*}-U_{i}^{*}\right)$. The identity $E_{i}^{*} \equiv E i-x i\left(\beta^{*}-\beta\right)$ is satisfied.

\section{Methodology}

\subsection{Data Collection and Sampling Techniques}

Primary and secondary data were used for this study. Primary data were collected in 2012 through the use of structured questionnaires. Secondary data was gathered from various publications relevant to the study. A multi-stage sampling technique was used to select cocoa farmers in the four (4) divisions of Ogun State.

\subsection{Empirical Model and Variables}

In this study, data collected was analyzed using descriptive statistics, Tobit Regression Model and Stochastic Metaproduction Frontier analyses. Descriptive statistics, including frequency counts, percentages and means, were used to analyze the socioeconomic characteristics of the respondents. A stochastic metaproduction frontier was used to determine the technical efficiency of the farms. A stochastic metaproduction frontier was used to obtain alternative estimates for the technical efficiencies of farmers in the different local governments in the state. Metaproduction frontier was used among farmers that operate under different technologies, and this is based on the hypothesis that all producers in different local government areas have potential access to the same technology.

\subsection{Model Specification}

The metafrontier production function model for farms in all local government areas of the cocoa sector is expressed by: 
The stochastic frontier production function is defined by:

$$
Y_{i}=f(m i, \alpha)+\varepsilon
$$

Where:

$\mathrm{Y}_{\mathrm{i}}=$ Output of ith cocoa farmers $(\mathrm{kg})$

$\mathrm{m}_{i}=$ Vector of inputs used by ith farmer

$\beta=$ Vector of unknown parameters

$\varepsilon=\mathrm{V}_{\mathrm{i}}-\mathrm{U}_{\mathrm{i}}$ is the decomposed error term

Explicitly this is stated as

$$
\ln Y=\beta 0+\beta_{1} \operatorname{lnm}_{1}+\beta 2 \operatorname{lnm}_{2}+\beta 3 \operatorname{lnm}_{3}+\beta 4 \operatorname{lnm}_{4}+V_{i}-U_{i}
$$

Where

$\ln Y_{i}=$ the natural logarithm of the total quantity of cocoa produced measured in kilograms,

$\mathrm{i}$ and $\mathrm{m}=$ the input $\mathrm{m}$ used by unit $\mathrm{i}$.

$\mathrm{m}_{1}=$ the total productive cocoa area in hectares;

$\mathrm{m}_{2}=$ the amount of fertilizers used in cocoa production measured in $\mathrm{kg}$;

$\mathrm{m}_{3}=$ the amount of labor, which includes both family, exchange, and hired labor in man-days;

$\mathrm{m}_{4}=$ the average age of cocoa trees measured in years.

$\mathrm{m}_{5}=$ the distance of the cocoa farm from the farmers house measured in $\mathrm{km}$;

$\mathrm{m}_{6}=$ the amount of chemicals used in cocoa production measured in litres.

The two components $V_{i}$ and $U_{i}$ were assumed to be independent of each other where, $V_{i}$ is two sided, normally distributed random error $\left(\mathrm{V}_{\mathrm{i}}-\mathrm{N}(0, \sigma 2 \mathrm{v})\right.$ and $\mathrm{Ui}$ are one sided, non-negative variables with a half-normal distribution $\left(\mathrm{U}_{\mathrm{i}}-\mathrm{N}(0, \sigma 2 \mathrm{u})\right.$, which was assumed to account for technical inefficiency in production (Coelli, 2007; Okoruwa et al., 2006; Awotide \& Adejobi, 2006).

The technical inefficiency effects $\mathrm{U}_{\mathrm{i}} \mathrm{s}$ are nonnegative random variables, and assumed to be independently distributed as truncations at zero of the normal distribution. Specifically,

$$
u_{i}=\delta_{0}+\sum_{j=1}^{m} \delta_{j} z_{i}^{j}+()_{i} .
$$

where

$\mathrm{z}_{\mathrm{j}}$ 's = farmer explanatory variables associated with technical inefficiencies.

$\mathrm{j}_{1}=$ the producers' level of education (number of completed years of schooling for the farmer);

$\mathrm{j}_{2}=$ the age of the farmer (in years)

$\mathrm{j}_{3}=$ marital status of the farmers

$\mathrm{j}_{4}=$ household size (numbers of person)

$\mathrm{j}_{5}=$ dummy variable used to measure if the farmer belongs to a farmer organization or association. The value is 1 if yes, and 0 otherwise

$\mathrm{j}_{6}=$ farmers experience (years)

$\mathrm{j}_{7}=$ cost of labour (naira);

$\mathrm{j}_{8}=$ cost of implement (naira);

$\mathrm{j}_{9}=$ income (naira);

$\mathrm{j}_{10}=$ occupation (dummy variable measured if the farmer main occupation is cocoa $=1$, and 0 otherwise);

$\delta 0$ and $\delta \mathrm{j}$ are parameters to be estimated and $\omega$ is a random variable with zero mean and finite variance defined by the truncation of the normal distribution such that $\omega_{i} \geq\left(\delta_{0}+\sum_{j} \overline{\delta_{j}} z_{i}^{j}\right)$ 
Tobit Regression Model was used to analyze the relationship between access to credit and technical efficiency among cocoa farmers in the study area. The model is stated as follows:

$$
Y^{*}=b^{\prime} X+U
$$

where

$\mathrm{Y}$ is the actual dependent variable, is only observed if $\mathrm{Y}^{*}>0$.

$\mathrm{X}$ is a k-vector of regressors, possibly including 1 for the intercept, and the error term $\mathrm{U}$ is $\mathrm{N}\left(0, \mathrm{~s}^{2}\right)$ distributed, conditionally on $\mathrm{X}$

Explicitly, the Tobit Model is stated as follows:

$$
Y=b_{1} X_{1}+b_{2} X_{2}+b_{3} X_{3}+b_{4} X_{4}+\ldots \ldots+b_{n} X_{n}+U .
$$

Where,

$\mathrm{Y}=$ dependent variable (The dependent factor in the model is Technical efficiency of the farms.)

$\mathrm{X}_{1}=$ marital status (dummy variable used to measure if the farmer is single, married and otherwise)

$\mathrm{X}_{2}=$ net farm income (naira)

$\mathrm{X}_{3}=$ age of farmers (years)

$\mathrm{X}_{4}=$ household size (numbers)

$\mathrm{X}_{5}=$ farmers experience (years)

$\mathrm{X}_{6}=$ level of education (years spent in formal educational institution)

$\mathrm{X}_{7}=$ amount of credit obtained (naira)

$\mathrm{X}_{8}=$ membership of association (dummy variable used to measure if the farmer belongs to a farmer organization or association. ( 1 if yes, and 0 otherwise)

$\mathrm{X}_{9}=$ cost of labour (naira)

$\mathrm{X}_{10}=$ cost of implement (naira)

$\mathrm{X}_{11}=$ age of cocoa trees (years)

$\mathrm{X}_{12}=$ cost of chemical (naira)

$\mathrm{X}_{13}=$ cost of fertilizer (naira)

$\mathrm{U}=$ Error term (which is assumed to have zero mean and constant variance (Koutsoyiannis, 1977).

\section{Results and Discussion}

Results from the analysis revealed that $50.0 \%$ of the cocoa farmers were between the ages of 40 to 55 years, which means that farmers engaged in the production of cocoa in the study area were in their active age and this suggest that they can easily adopt new innovations that could enhance cocoa production, while $43.3 \%$ were between the ages of $56-65$ years. Table 1 also revealed that most of the respondents were married (84.2\%) which implied that majority of the cocoa farmers would be more relatively stable in their place of farming than their single counterparts. Stability of farmers in their places of farming can enhance cocoa production. Precisely, $32.5 \%$ of the farmers had no form of education, while about $51.7 \%$ had 6 years of education and $15.0 \%$ of the total respondents had above 6 years of formal education. This might have effect on the administrative productivity for credit access processing since they have low literacy level. The farmers sampled are not likely to appreciate the need to adopt new technology which can enhance their production efficiency. Table 1 also shows that $94.2 \%$ of the farming households have $2-10$ persons in their households. This is an indication that farming household may spend less on hired labour while they will enjoy the use of family labour otherwise it may also mean that the higher the number of persons per household the higher the number of mouths to feed and needs to meet with the little income available.

Also, Table 1 shows the years of farming experience of respondents, $91.8 \%$ had experience of between 10 and 40 years which should positively influence output, all things being equal. All the sampled farmers are involved in farming activities as primary occupation but only $78.3 \%$ had their income solely from farming activities while $21.3 \%$ of the households depend on non-farm incomes in addition to the farm income and this shows the importance of non-farm employment in income diversification among rural farm households. Furthermore, Table 1 revealed that $85.0 \%$ of the farmers do not have access to credit; this implies that despite the existence of the formal institutions, especially the commercial banks, their financial services in the form of loans are not easily 
accessible to the enterprises. While banks can be used for savings, the farmers do not have access to their credit facilities and there have not been corresponding efficiency gains in the services offered to farmers. Result from Table 1 also reveals that $58.3 \%$ of the cocoa farmers belong to the farmers association. Membership of the association is part of social capital, and the sharing of information on crop husbandry at association levels tends to filter to members and non-members and this as well enhances productivity.

\subsection{Factors Influencing the Technical Efficiency of Cocoa Farmers}

The single-stage maximum likelihood procedure of the LIMDEP 7.0 software was used to estimate the parameters of the stochastic frontiers and efficiency determinants for each division and for pooled data. Table 2 presents estimates of the parameters of the stochastic frontiers for all the divisions separately and also using pooled data. Therefore a LR test was performed in order to see if all the divisional stochastic frontiers share the same technology. The generalized likelihood-ratio (LR) test statistic for the null hypothesis that the divisional frontiers are identical for all cocoa farmers in Ogun State was calculated after estimating the stochastic frontier by pooling the data from all the four divisions. The value of the LR statistic was 51.12 , which is highly significant. This result strongly suggests that the four divisional stochastic frontiers for cocoa farmers in Ogun State are not the same. Estimates of the stochastic frontier models are summarized in Table 3. The stochastic frontier estimates from Table 2 show that cocoa farms in Ogun State have high technical efficiency scores with a mean efficiency of $0.41,0.94,0.32$ and 0.71 for farms in Yewa, Ijebu, Remo and Egba respectively. The constant of the regression, which is an index for the level of technology, is significant and higher for farms in Yewa (10.17). Estimates from the results show that farm size and labour were statistically significant at $1 \%$ in Yewa, and farm size is significant at $10 \%$ in Remo, while farm distance, chemicals and fertilizer are significant at $5 \%$ and $10 \%$. Farm distance, chemicals and fertilizer are found to be significant in the estimated stochastic metafrontier production function.

Table 1. Socioeconomic characteristics of the respondents

\begin{tabular}{|c|c|c|c|}
\hline Variables & Frequency & Percent & Mean \\
\hline \multicolumn{4}{|l|}{ Marital Status } \\
\hline Married & 101 & 84.2 & \\
\hline Widowed & 10 & 8.3 & \\
\hline Divorced & 9 & 7.5 & \\
\hline \multicolumn{4}{|l|}{ Age (years) } \\
\hline $40-<55$ & 60 & 50.0 & 55.48 \\
\hline $55-<70$ & 52 & 43.3 & \\
\hline 70 above & 8 & 6.7 & \\
\hline \multicolumn{4}{|l|}{ Education level } \\
\hline No formal education & 39 & 32.5 & 4.83 \\
\hline 6 years & 62 & 51.7 & \\
\hline 12 years & 18 & 15.0 & \\
\hline 12 years and above & 1 & 0.8 & \\
\hline \multicolumn{4}{|c|}{ Household size (No. of persons) } \\
\hline $1-5$ & 79 & 65.8 & 5.28 \\
\hline $6-10$ & 34 & 28.4 & \\
\hline 11 above & 7 & 5.8 & \\
\hline \multicolumn{4}{|l|}{ Farming experience } \\
\hline $10-<25$ & 45 & 37.5 & 29.89 \\
\hline $25-<40$ & 64 & 53.3 & \\
\hline 40 and above & 11 & 9.2 & \\
\hline
\end{tabular}




\begin{tabular}{|c|c|c|c|}
\hline \multicolumn{4}{|l|}{ Occupation } \\
\hline Other occupation & 26 & 21.7 & \\
\hline Farming only & 94 & 78.3 & \\
\hline \multicolumn{4}{|l|}{ Income (Naira) } \\
\hline $25000-150000$ & 38 & 31.7 & 294416.67 \\
\hline $151000-275000$ & 65 & 54.2 & \\
\hline 276000 and above & 17 & 14.1 & \\
\hline \multicolumn{4}{|c|}{ Membership of association } \\
\hline Non members & 50 & 41.7 & \\
\hline Members & 70 & 58.3 & \\
\hline \multicolumn{4}{|l|}{ Credit access } \\
\hline No access to credit & 102 & 85.0 & \\
\hline Access to credit & 18 & 15.0 & \\
\hline Total & 120 & 100 & \\
\hline
\end{tabular}

Source: Field survey 2012. Note: N165 =1\$.

Table 2. The maximum likelihood estimates of the stochastic frontiers with the preferred inefficiency models for cocoa farmers in different divisions in Ogun State, together with estimates of parameters of the metafrontier production function

\begin{tabular}{|c|c|c|c|c|c|c|}
\hline Variable & Coefficient & Yewa & Ijebu & Remo & Egba & Pooled \\
\hline Constant & $\beta 0$ & $10.17(7.005)^{* * *}$ & $3.756(1.716) *$ & $5.352(3.864)^{* * *}$ & $5.933(4.279)^{* *}$ & $7.551(9.079)^{* *}$ \\
\hline Farm size (ha) & $\beta 1$ & $0.923(2.773)^{* * *}$ & $0.518(1.183)$ & $0.451(1.664)^{*}$ & $-0.523(-1.523)$ & $0.317(2.167)^{* *}$ \\
\hline Cocoa age (Yrs) & $\beta 2$ & $-0.485(-1.025)$ & $0.823(1.420)$ & $0.437(1.378)$ & $0.653(1.571)$ & $-0.110(0.005)$ \\
\hline Farm Distance (km) & $\beta 3$ & $0.966(0.412)$ & $0.335(1.252)$ & $0.385(2.171)^{* *}$ & $-0.072(-0.185)$ & $0.278(4.830)^{* *}$ \\
\hline Fertilizer (kg) & $\beta 4$ & $-0.188(-1.302)$ & $-0.147(-0.591)$ & $-0.478(-2.835)^{* * *}$ & $-0.361(-1.591)$ & $-0.293(-6.050)^{* *}$ \\
\hline Chemicals (ltr) & $\beta 5$ & $-0.229(-1.038)$ & $0.223(0.852)$ & $0.373(2.217)^{* *}$ & $0.612(0.321)$ & $0.194(1.873)^{*}$ \\
\hline Labour (mandays) & $\beta 6$ & $-0.524(-1.619)^{*}$ & $-0.305(0.730)$ & $0.061(0.310)$ & $0.341(0.730)$ & $-0.034(0.277)$ \\
\hline \multicolumn{7}{|l|}{ Variance Parameters } \\
\hline$\sigma^{2}=\left(\sigma_{\mathrm{l}}^{2}-\sigma_{\mathrm{\gamma}}^{2}\right)$ & & $1.294(0.663)$ & $3.346(1.041)$ & $1.531(0.550)$ & $3.282(1.004)$ & $905.0(0.000)$ \\
\hline$\gamma=\sigma_{u}^{2} /\left(\sigma_{u}^{2}+\sigma_{v}^{2}\right)$ & & $0.681(2.416)$ & $1.227(4.313)$ & $0.484(1.688)$ & $0.937(2.973)$ & $1.327(12.532)$ \\
\hline Log likelihood & & -23.24 & -36.34 & -11.74 & -26.12 & -123.0 \\
\hline \multicolumn{7}{|l|}{ Inefficiency effects } \\
\hline Constants & $\delta 0$ & $0.044(0.084)$ & $2.661(1.692)^{* *}$ & $1.025(2.498)^{* * *}$ & $1.872(1.591)^{* *}$ & $1.152(1.438)$ \\
\hline Marital Status & $\delta 1$ & $-0.037(-0.830)$ & $-0.269(-2.075)^{*}$ & $-0.072(-1.750)^{* * *}$ & $.144(1.198)$ & $-0.076(-1.013)$ \\
\hline Age & $\delta 2$ & $0.015(1.645)^{* *}$ & $-0.014(-0.602)$ & $-0.004(-0.480)$ & $-.006(-0.317)$ & $0.007(0.551)$ \\
\hline Education & $\delta 3$ & $-0.019(-1.753)^{* *}$ & $0.010(0.326)$ & $0.000(0.031)$ & $-.013(-0.531)$ & $-0.008(-0.414)$ \\
\hline Household size & $\delta 4$ & $0.029(1.056)$ & $-0.069(-0.907)$ & $-0.058(-2.284)^{*}$ & $.039(0.697)$ & $0.016(0.409)$ \\
\hline Experience & $\delta 5$ & $-0.012(-1.772)^{* *}$ & $0.016(1.034)$ & $0.006(0.751)$ & $-.006(-0.408)$ & $-0.003(-0.312)$ \\
\hline Occupation & $\delta 6$ & $-0.050(-0.425)$ & $-0.492(-1.617)^{* *}$ & $-0.154(-1.186)$ & $-0.961(-3.009) * * *$ & $-0.378(-1.778)^{*}$ \\
\hline Livelihood income & $\delta 7$ & $-0.005(-0.989)$ & $-3.305(-1.757)^{* *}$ & $3.007(0.051)$ & $-6.705(-2.357)^{*}$ & $-2.705(-2.020)^{*}$ \\
\hline Annual Income & $\delta 8$ & $4.009(0.012)$ & $1.007(0.247)$ & $-2.207(-0.780)$ & $1.707(0.195)$ & $-2.008(-0.037)$ \\
\hline Association & $\delta 9$ & $-0.171(-1.809)^{* *}$ & $-1.214(-3.492)^{* * *}$ & $-0.213(-1.608)^{* *}$ & $.131(0.580)$ & $-0.523(-2.974)^{* * * *}$ \\
\hline Labour cost & $\delta 10$ & $1.007(0.177)$ & $-3.307(-0.230)$ & $-3.108(-0.037)$ & $-1.806(-1.696)^{*}$ & $-1.006(-1.208)$ \\
\hline Implement cost & $\delta 11$ & $-2.006(-0.438)$ & $1.605(1.122)$ & $-4.306(-0.549)$ & $1.705(1.282)$ & $3.105(2.972)^{* * *}$ \\
\hline
\end{tabular}

Source: Field survey 2012

Note: Variables in parentheses are asymptotic t-ratios.

$*, * * *$, and $* *$ denote significant using a one-tailed test at the 1,5 , and $10 \%$ levels, respectively. 


\subsection{Explaining Technical Inefficiency}

The parameter estimates of the inefficiency effects stochastic production frontier model used to identify the factors influencing farmers' levels of technical inefficiency are listed in the lower panel of Table 2. The results show that coefficients of age, education, experience, membership of association, marital status, occupation, livelihood income, household size, and labour cost have a significant impact on technical inefficiency among cocoa farmers. Among the explanatory variables in the four divisions, in Yewa, coefficient of age had a positive significant affect at 5\% level, also coefficient of educational level, farmers experience, as well as membership of association were negative and statistically significant at $5 \%$ level. The negative and significant coefficient for some of the variables indicates that the variables were important factors enhancing cocoa productivity. Dzimadzi et al, (2001) in the case of a targeted input safety net programme found that problems of literacy and numeracy led farmers to use the inputs inappropriately. In some cases, inputs were used on larger areas than the technical specifications contained in the leaflets and in other cases the instruction conflicted with the traditional farming systems.

In Ijebu, results showed inverse relationship between output and marital status, occupation, livelihood income and association of respondents. All these variables were significant at 5\% except membership of association which is significant at $1 \%$ level. Also, variables such as marital status which is significance at $1 \%$, household size is significant at $10 \%$ and membership of association which is significant at $5 \%$ were among the explanatory variables in Remo Division. This implies that as the number of household members increase, the farmers will experience reduction in efficiency. Also, farmers belonging to cocoa farmers association tends to have a reduce output. In Egba division, coefficient of variables such as occupation, livelihood income and labour cost were negatively significant. This implies that increase in the labour cost will bring about reduction in the inefficiency level of the farmers.

\subsection{Technical Efficiencies and Technology Gap Ratios}

The values of the TGR, together with the technical efficiencies obtained from the divisional stochastic frontiers (TE) and the metafrontier (TE*) were computed for all farmers in Ogun State. Summary statistics for these measures are presented in Table 4. The TGR values can be interpreted as the mean technological gap between the metafrontier and the divisional efficiency frontier for a given vector of inputs. These results imply that the mean producer in Ijebu and Egba, if he or she were technically efficient, could still increase output by $6 \%$ and $29 \%$, if he or she were to adopt the most efficient meta-technology for the division. Also, from Table 4, the TGR gap for the mean producer was smaller in Yewa and Remo, ranging from 58\% to 68\%, indicating that the extant technologies in these divisions is close to the possibilities' frontier of the meta-technology.

According to the model results, the smallest yield gain would occur in Remo and Yewa, while farmers from Ijebu and Egba would see the largest overall gain. On the basis of this analysis, the expected returns from increased investment in extension, improved infrastructure and credit institutions should be highest in Yewa and Remo.

Table 4. Summary statistics for the TGR and the TE obtained from the divisional stochastic frontiers and the metafrontier production function for Ogun State cocoa farmers

\begin{tabular}{lcccc}
\hline & Yewa & Ijebu & Remo & Egba \\
\hline TGR & $0.39(0.23)$ & $0.87(0.82)$ & $0.30(0.23)$ & $0.66(0.65)$ \\
Divisional TE & $0.42(0.18)$ & $0.94(0.65)$ & $0.32(0.18)$ & $0.71(0.51)$ \\
Metafrontier TE* & $0.16(0.04)$ & $0.82(0.53)$ & $0.10(0.04)$ & $0.47(0.33)$ \\
\hline
\end{tabular}

Figures in parentheses are standard deviations. TE $=$ technical efficiencies; TGR = technology gap ratio.

\subsection{Relationship between Access to Credit and Technical Efficiency among Cocoa Farmers in Ogun State}

The parameters of the Tobit model are presented in Table 6. From the results, the sigma value was 15.94, with a p-value of less than 0.01 and log likelihood function of -17.65 . Hence, sigma square was statistically significant, thus indicating that the model displayed a good fit and was correctly specified. Results showed that amount of credit obtained, membership of a farmers' association, amount of fertilizer used, educational status and the amount of chemical used has significant influence on cocoa productivity. The coefficients obtained implied that these factors influenced technical efficiency. The results show that there was a positive and statistically 
significant effect of credit use on technical efficiency at $1 \%$ level, implying that increasing credit use would enhance technical efficiency of sampled farms. This result agrees with a priori expectations and the reports from Nwaru (2004), Nwaru et al. (2006) and Okoye et al. (2007).

There was a positive and significant difference between membership in a farmers' association and technical efficiency $(\mathrm{P}<0.1)$, suggesting that farmers who belong to an organization are likely to benefit from better access to inputs and to information on improved farming practices. This result is in consonance with a priori expectations and the report from Nwaru et al. (2006) who noted that farmer associations is expected to increase the farmer's interactions with his fellow farmers and other entrepreneurs which would in turn increase his capacity to access current pieces of information on economic activities within his locality and even beyond.

Results from Table 6 also show that amount of fertilizer used and chemical used has significant effects on the technical efficiency of the cocoa farms. This enhances the production of more cocoa as fertilizer and chemical will be available for farming operations, which will in turn increase the productivity of the farm. This result highlights the importance of fertilizer and chemical in increasing crop yield as low fertilizer and chemical usage tends to decrease agricultural growth. The results also show that coefficient of educational background was positively significant. This indicates that the efficiency of cocoa farmers, who used improved technologies increases with increase in years of schooling. Education enhances the acquisition and utilization of information on improved technology by farmers (Idiong, 2006; Onyeakwu et al., 2005) and this significantly increases efficiency (Rahman \& Hasan, 2006).

Table 6. Tobit model estimates the relationship between access to credit and technical efficiency among cocoa farmers in Ogun State (Dependent variable $=$ Technical Efficiency indices)

\begin{tabular}{lccc}
\hline Variable & Coefficients & Standard Error & t-value \\
\hline (Constant) & $0.493^{*}$ & 0.298 & 1.652 \\
Marital Status & 0.015 & 0.031 & 0.484 \\
Age of farmers & 0.002 & 0.006 & 0.335 \\
Educational level & $0.012^{*}$ & 0.007 & 1.714 \\
Household size & 0.013 & 0.016 & 0.813 \\
Years of Experience & -0.002 & 0.004 & -0.500 \\
Amount of credit obtained & $0.943^{*}$ & 0.572 & 1.649 \\
Membership association & $0.447^{* * *}$ & 0.165 & 2.709 \\
Labour cost & -0.179 & 0.349 & -0.513 \\
Implement cost & 0.719 & 0.487 & 1.476 \\
Age of cocoa trees & 0.604 & 0.443 & 1.363 \\
Amount of Chemical & $0.812^{* * *}$ & 0.119 & 1.824 \\
Amount of Fertilizer & $0.733^{*}$ & 0.443 & 1.655 \\
Net farm income & -0.114 & 0.209 & -0.545 \\
\hline R-squared & 0.235 & Sigma & 15.94 \\
Adjusted R-squared & 0.125 & & $\mathrm{~N}$ \\
Log-likelihood & -17.65 & & \\
\hline
\end{tabular}

Source: Field survey 2012.

Note: $* * *$ and $*$ denote significant using a one-tailed test at the 1 and $10 \%$ levels, respectively.

\subsection{Concluding Remarks}

The present study focused on a metafrontier analysis of access to credit and technical efficiency among smallholder cocoa farmers in Ogun State. Evidence from the study revealed that majority of the poor cocoa farmers do not have access to credit from formal institution. The results of the study revealed that most of the farmers borrowed relatively small size of loans for short duration. Also, it is concluded that membership of the 
association is part of social capital, and the sharing of information on crop husbandry at association levels tends to filter to members and non-members and this as well enhances productivity. Evidence from the metaproduction frontier show that the mean productivity potential and technical efficiency ratios give additional explanation compared to the analysis based only on individual stochastic production frontiers. The productivity potential ratio plays an important part in explaining the ability of cocoa farmers in one division to compete with other farmers from different division at the state level. This ratio provides an estimate of the technology gap between the country and the region as a whole. The study also revealed that improvement in provision of agricultural credit (with the intention of taking smallholders from off-farm activities) along with extension services are likely to lead to improved smallholder technical efficiency. Based on the results, policy environment whereby individual cocoa farmers may have access to formal credit from banks and other agency, by forming groups, by means of using land use right certificates and also guarantor as a collateral would be a right direction in boosting cocoa production in the sub-region.

\section{References}

Abang, S. O. (1984). Stabilization policy: An economic analysis and evaluation of its implication for Nigerian Cocoa farmers. PhD Thesis, Oklahoma State University, Stillwater.

Ajakaiye, M. B. (1991). NACA as a development Finance Intermediary: its impact on the development process. The DemocrSat Weekly, Sunday, July 7th.

Awotide, D. O., \& Adejobi, A. O. (2006). Technical efficiiency and costs of production among plantain farmers in Oyo State, Nigeria. Moor Journal of Agricultural Research, 7(2), 107-113.

Awotide, D. O., Ololagbose, O., Kehinde, A. L., \& Bamiro, O. M. (2009). Credit access, farm size and cost inefficiency in maize production in Yewa North Area, Ogun State, Nigeria. Nigeria Farman Journal, 10(2), 22-29.

Barry, P. J., \& Robinson, L. J. (2001). Agricultural Finance: Credit, Credit Constraints and consequences. In B. Gardner and G. Rausser (Eds.), Handbook of Agricultural Economics, Vol. 1A, 513-71. Amsterdam: Elsevier.

Battese, G. E., \& Rao, D. S. P. (2001). Productivity Potential and Technical Efficiency Levels of firms in Different Regions Using a Stochastic Frontier Metaproduction Function Model. CEPA Working Papers No. 6, School of Economics, University of New England, Armidale.

Bravo-Ureta, B. E., \& Pinheiro, A. E. (1997). Technical, Economic and Allocative Efficiency in Peasant Farming: Evidence from the Dominican Republic. Developing Economies, 35, $48-67$. http://dx.doi.org/10.1111/j.1746-1049.1997.tb01186.x

Carter, M. R. (1989). The Impact of Credit on Peasant Productivity and Differentiation in Nicaragua. Journal of Development Economics, 31, 13-36. http://dx.doi.org/10.1016/0304-3878(89)90029-1

Coelli, T. J. (1995). Recent Developments in Frontier Modeling and Efficiency Measurement. Australian Journal of Agricultural Economics, 39(3), 219-245. http://dx.doi.org/10.1111/j.1467-8489.1995.tb00552.x

Dicken, P. (2007). Global Shift: Mapping the Changing Contours of the World Economy (5th ed.) London, California, New Delhi: SAGE Publications Inc.

Dorfman, J. H., \& Koop, G. (2005). Current Developments in Productivity and Efficiency Measurement. Journal of Econometrics, 126, 233-240. http://dx.doi.org/10.1016/j.jeconom.2004.05.001

Dzimazdi, C., Chinsinga, B., Chaweza, R., \& Kambewa, P. (2001). Targeted Inputs Programme (TIP) 2000/01: Agricultural Communications. Final Report of an Evaluation Commisioned by Ministry of Agriculture and Irrigation (Malawi).

Eswaran, M., \& Kotwal, A. (1990). Implications of credit constraints for risk behavior in less developed economies. Oxford Economic Papers, 42(2), 473-482.

Feder, G., Lau, L. J., Lin, J. Y., \& Luo, X. (1990). The relationship between credit and productivity in Chinese agriculture: A microeconomic model of disequilibrium. American Journal of Agricultural Economics, 72, 1151-1157. http://dx.doi.org/10.2307/1242524

Folayan, J. A., Daramola, G. A., \& Oguntade, A. E. (2006) Structure and performance evaluation of cocoa marketing institutions in South-Western Nigeria: An economic analysis. Journal of Food, Agriculture and Environment, 4(2), 123-128.

Guirkinger, C., \& Boucher, S. (2005). Credit constraints and Productivity in Peruvian Agriculture. Department 
of Agricultural and Resource Economics, University of California - Davis, Mimeo.

Hayami, Y. (1969). Sources of Agricultural Productivity Gap among Selected Countries. American Journal of Agricultural Economics, 51, 564-575. http://dx.doi.org/10.2307/1237909

Hayami, Y., \& Ruttan, V. W. (1970). Agricultural Productivity Differences among Countries. American Economic Review, 60, 895-911.

Hussein, H. K., \& Ohlmer, B. O. (2008). Influence of Credit Constraint on Production efficiency: The Case of Farm Households in Southern Ethiopia. Department of Economics, Swedish University of Agricultural Sciences, Sweden.

Idiong, I. C. (2006). Evaluation of technical, allocative and economic efficiencies in rice production systems in Cross River State, Nigeria. Unpublished Ph.D Dissertation, Michael Okpara University of Agriculture, Umudike, Abia State, Nigeria.

Lau, L. L., \& Yotopoulos, P. A. (1989). The Meta-production Function Approach to Technological Change in World Agriculture. Journal of Development Economics, 31, 241-269. http://dx.doi.org/10.1016/0304-3878(89)90014-X

Manyoug, V. M., Ikpi, A., \& Olayemi, J. K. (2004). Agriculture in Nigeria: Identifying Opportunities for Increased Commercialization and Investment. International Institute of Tropical Agriculture

Nwaru, J. C. (2004). Rural Credit Markets and Arable Crop Production in Imo State of Nigeria. PhD Dissertation, Department of Agricultural Economics, Michael Okpara University of Agriculture, Umudike, Nigeria.

Nwaru, J. C., Onyenweaku, C. E., \& Nwosu, A. C. (2006). Relative Technical Efficiency of Credit and Non Credit User Crop farmers. African Crop Science Journal, 14(3), 241-251.

Ogunma, N. N. O. (1998). Performance of the Imo Cooperative Financing Association in Credit Extension Services to Small-Scale farmers in the State. Nigerian Journal of Technical Education, 15(2), 183.

Okoruwa, V. O., Ogundele, O. O., \& Oyewusi, B. O. (2006). Efficiency and productivity of farmers in Nigeria: A study of rice farmers in North Central Nigeria. A poster paper prepared for presentation at the International Association of Agricultural Economists Conference (pp. 12-18), Gold Coast, Australia,.

Okoye, B. C., Onyenweaku, C. E., \& Asumugha, G. N. (2007). Technical Efficiency of Small Holder Cocoyam Production in Anambra State, Nigeria. A Cobb-Douglas Stochastic Frontier Production Approach. Journal of Agricultural Research and Policies, 2(2), 27-31.

Olayemi, J. K. (1973). Some economic characteristics of peasant agriculture in the cocoa belt of Western Nigeria. Bulletin of Rural Economics and Sociology, 1, 24-30.

Olayide, S. O. (1969). Some estimates of supply and demand elasticities for selected commodities in Nigeria's foreign trade. Journal of Business and Social Studies, 1(9), 176-193.

Omonona, B. T., Akinterinwa, A. T., \& Awoyinka, Y. A. (2008). Credit Constraint and Output Supply of Cowan Farmers in Oyo state Nigeria. European Journal of Social Sciences, 6(3), 382-390.

Onyeakwu, C. E., Igwe, K. C., \& Mbanasor, J. A. (2005). Application of stochastic frontier production function to the measurement of technical efficiency in yam production in Nassarawa State, Nigeria. J. Sust. Trop. Agric. Res., 13, 20-25.

Petrick, M. (2005). Empirical Measurement of Credit Rationing in Agriculture: A Methodological Survey. Agricultural Economics, 33(2), 191-203. http://dx.doi.org/10.1111/j.1574-0862.2005.00384.x

Rahman, S., \& Hasan, M. K. (2006). Efficiency effects of environmental and managerial factors: The case of wheat producers in Bangladesh. The Rural Citizen: Governance, Culture and Wellbeing in the 21st Century.

Sial, M. H., \& Carter, M. R. (1996). Financial market efficiency in an Agrarian economy: Micro econometric Analysis of the Pakistani Punjab. The Journal of Development Studies, 32(5), 771-798. http://dx.doi.org/10.1080/00220389608422439

Vos, J. G. M., Krauss, U., Petithuguenin, P., Perreira, L., \& Nanga, C. (2002). Global Co-ordination Group on Sustainable Cocoa Economy: Achieving more efficient knowledge transfer. 


\section{Copyrights}

Copyright for this article is retained by the author(s), with first publication rights granted to the journal.

This is an open-access article distributed under the terms and conditions of the Creative Commons Attribution license (http://creativecommons.org/licenses/by/3.0/). 